\title{
LETRAMENTO CIENTÍFICO, GÊNEROS TEXTUAIS E ENSINO DE LÍNGUAS: UMA CONTRIBUIÇÃO NA PERSPECTIVA DO INTERACIONISMO SOCIODISCURSIVO
}

\author{
SCIENTIFIC LITERACY, GENRES AND LANGUAGE TEACHING: \\ A CONTRIBUTION FROM THE SOCIO-DISCURSIVE \\ INTERACTIONISM PERSPECTIVE
}

\author{
Tânia Guedes Magalhães ${ }^{1}$ \\ Vera Lúcia Lopes Cristovão²
}

\begin{abstract}
Resumo: Nesta pesquisa, analisamos a relaçăo entre letramento científico e ensino de línguas, perante a busca por práticas que ultrapassem uma transposiçấo de gêneros textuais para a escola de forma redutora, como exercícios analíticos sem circulaçâo social das produçóes autorais dos discentes. Propomos uma discussăo teórica sobre letramento científico, bem como uma reflexâo sobre práticas escolares realizadas em língua materna e estrangeira que buscaram ressignificar a relaçấo entre conceitos científicos e a apropriaçâo do conhecimento na escola via oralidade e escrita. Os resultados revelam que há efetiva apropriaçăo de conhecimentos de linguagem numa perspectiva investigativa, atrelada à possibilidade de participaçâo social nas atividades humanas, o que pôde ser alcançado pela interaçăo por meio dos gêneros textuais nas práticas pedagógicas realizadas.
\end{abstract}

Palavras-chave: Gêneros textuais. Ensino de linguagem. Letramento científico.

Abstract: This research work aims at analysing the relationship between scientific literacy and language teaching, in the search for practices that overcome the mere transposition of genres to school reductively, with analytical exercises without social circulation of the students ' productions as authors. We propose a theoretical discussion about scientifc literacy under the perspective of different authors, as well as a reflection about school practices carried out in both mother tongue and foreign language teaching/learning situations where there was an attempt to resignify the relationship between scientific concepts and knowledge appropriation at school via oral and written productions. The results of the observation of such practices reveal that there is actual appropriation of language knowledge in an investigative perspective, linked to the possibility of social

1 Doutora em Letras - Professora dos cursos de Letras e Pedagogia da UFJF. Programa de Pós-Graduaçâo em Educaçăo, linha Linguagens, Culturas e Saberes. tania.magalhaes95@gmail.com

2 Doutora em Linguística Aplicada e Estudos da Linguagem - Professora Associada da UEL. Programa de Pós-Graduaçâo em Estudos da Linguagem. veraluciacristovao@gmail.com 
participation in human activities; that could be achieved by means of the interaction promoted by the use of genres in the pedagogical practices carried out.

Keywords: Genres. Language teaching. Scientific literacy.

\section{INTRODUÇÃO}

As reflexóes que aqui se apresentam sâo oriundas das discussóes empreendidas no âmbito dos grupos de pesquisa Linguagem e Educaçăo (UEL) e Linguagem, Ensino e Práticas sociais (UFJF) ${ }^{3}$, nos quais temos aprofundando nossos estudos nas relaçóes entre linguagem, processos educativos e letramentos. Tais grupos têm se dedicado a pesquisas no campo de estudos da Linguística Aplicada ao ensino de língua materna e estrangeira, vinculando-nos às perspectivas de estudos de letramento, referente aos impactos e às repercussóes dos usos da escrita na sociedade, bem como dos resultados da apropriaçấo da linguagem para o desenvolvimento humano. Tais estudos têm trazido implicaçōes importantes para a relaçâo universidade e escola, a formaçăo de professores, a elaboraçăo de materiais didáticos e o desenvolvimento de capacidades de linguagem de discentes da escola básica e da formaçáo inicial de professores, que têm sido objeto de pesquisas nesses grupos.

Os estudos sobre letramento científico também têm trazido importantes repercussôes para a escola contemporânea. Sáo várias contribuiçôes nos campos dos estudos do Ensino de Ciências e Educaçăo Científica (SANTOS, 2007; PAULA, LIMA, 2007; TEIXEIRA, 2013; SUISSO, GALIETA, 2015). Entretanto, na perspectiva da Linguística Aplicada, o tema parece ser mais recente, tendo menos contribuiçóes que explicitamente se alinhem a essa vertente (SILVA, 2016). Trabalhos recentes têm demonstrado a pertinência da abordagem do tema no âmbito da Linguística Aplicada (MOTTA-ROTH, 2011; SILVA, 2016; SILVA, SOUSA, ARAÚJO, 2017; CORDEIRO, 2017). Ademais, para além de considerarmos o tema como da maior relevância, ele parece ganhar mais impulso ainda atualmente, sobretudo com efeitos para a escola básica e para a formaçâo inicial de professores, quando é mencionado em documentos para a Educaçăo, como o edital do Programa Institucional de Bolsa de Iniciaçăo à Docência (2016) ${ }^{4}$ em que letramento científico figura como um dos "eixos estruturantes para organizaçăo dos projetos institucionais do PIBID". O alcance desse direcionamento resulta, certamente, em projetos que, no mínimo, tangenciam o tema e, de forma mais aprofundada, podem romper com a fragmentaçăo das disciplinas escolares e com a apropriaçăo de conhecimentos científicos pela mera transmissăo ou reproduçăo de saberes.

Este trabalho, entâo, se insere no fluxo das discussōes sobre letramento científico (LC) e suas relaçōes com trabalhos da Linguística Aplicada (SILVA, 2016; 2017; MOTTAROTH, 2011). Nossa contribuiçấo neste artigo pretende abordar conceitos oriundos de

3 Grupo de Pesquisa Linguagem e Educaçăo - Universidade Estadual de Londrina, coordenado pela $2^{a}$ autora; e Grupo Linguagem, Ensino e Práticas sociais - LEPs (coordenado pela $1^{\mathrm{a}}$ autora). O grupo LEPs está alocado no Núcleo de Pesquisa Formaçăo de Professores, Alfabetizaçăo, Linguagem e Ensino (FALE) - UFJF.

4 https://www.capes.gov.br/images/stories/download/legislacao/15042016-Portaria-46-RegulamentoPIBID-completa.pdf 
diversas correntes de LC, relacionando-o aos pressupostos teórico-metodológicos do Interacionismo Sociodiscursivo (ISD), de forma a mostrar como tal relaçáo tem sido profícua para as práticas educativas que envolvem noçōes teóricas desses dois campos (LC e ISD), permitindo relacionar a aprendizagem à apropriaçăo e ao desenvolvimento da linguagem em práticas sociais de uso da língua. Trazemos para a discussáo exemplos de práticas escolares vinculadas aos grupos que coordenamos, práticas essas de Língua Portuguesa e Língua Inglesa, que buscam ressignificar a relaçăo entre conceitos científicos e a apropriaçăo do conhecimento na escola pelo domínio dos gêneros textuais para participaçăo social efetiva.

Para cumprir nosso objetivo, apresentamos, numa primeira seçăo, diferentes concepçóes de letramento científico, advindas de autores tanto do campo do Ensino de Ciências quanto do campo da Linguística Aplicada. Em seguida, relacionamos tal perspectiva aos conceitos oriundos do Interacionismo Sociodiscursivo, enfocando questōes caras a esse viés, como o agir, os gêneros textuais e o desenvolvimento humano. Por fim, apresentamos práticas que revelam uma apropriaçăo de linguagem vinculada à participaçăo em atividades sociais, via apropriaçăo dos gêneros textuais nas práticas pedagógicas realizadas. Esperamos, com essa abordagem, trazer contribuiçóes para a problematizaçâo da educaçăo linguística contemporânea, contribuindo com transformaçōes necessárias às escolas.

\section{BREVE ABORDAGEM DE ESTUDOS SOBRE LETRAMENTO CIENTÍFICO}

O termo scientific literacy é conhecido desde ao final da década de 1950 (MILLER, 1983; HURD, 1997, LAUGKSCH, 2000; DEBOER, 2000, CUNHA, 2012); é um termo5 usado para descrever a familiaridade desejável com a ciência por parte do público em geral. Para os vários autores que estudam a temática, há certas diferenças entre os conceitos de alfabetizaçăo/letramento científico (AC/LC), que repercutem nas pesquisas de formas diversas. No Brasil ${ }^{6}$, pelos estudos ocorridos nos últimos 30 anos na área de alfabetizaçăo e letramento, polarizou-se o uso de alfabetizaçăo (CHASSOT, 2003, KRASILCHIK; MARANDINO, 2007; TEIXEIRA, 2013, entre outros) ou letramento científico (PAULA e LIMA, 2007; SANTOS, 2007; MARTINS, 2010; MORTMER, VIEIRA, ARAÚJO, 2010; MOTTA-ROTH, 2011, entre outros). Esses usos săo flutuantes ${ }^{7}$ e referem-se às diferentes concepçōes na relaçāo entre conhecimento, discurso científico, leitura e escrita.

Para além dessa polarizaçâo, o tema é de interesse público, já que estudos demonstram a baixa capacidade do brasileiro de compreender textos científicos (85\% dos entrevistados em pesquisa do Ministério da Ciência e Tecnologia (MOTTA-ROTH, 2011), de diferentes camadas sociais, afirmaram náo compreenderem textos sobre ciências). Em pesquisa mais recente, o Instituto Abramundo

5 Traduçâo livre de "Scientific literacy is a term that has been used since the late 1950s to describe a desired familiarity with science on the part of the general public." (DEBOER, 2000).

6 Literacy pode ser traduzido para o português como alfabetizaçăo ou letramento.

7 Em funçâo do objetivo do artigo, nâo vamos discutir as diferentes concepçôes que cercam as perspectivas de alfabetizaçăo e/ou letramento científico. 
evidencia que 48\% da populaçâo entrevistada "foi classificada no nível de letramento científico rudimentar, enquanto apenas $5 \%$, foram classificadas no nível de letramento científico proficiente" (GOMES, 2015, p. 34). A questăo da proficiência leitora está fortemente envolvida no conceito de letramento científico, que apresentamos adiante. Para a escola, na aprendizagem de saberes científicos, os pesquisadores vinculados aos campos da Educaçâo em Ciências (SANTOS, 2007; MORTMER, 2001) e da Linguística Aplicada (MOTTA-ROTH, 2011; SILVA, 2016) têm reforçado que, para haver apropriaçăo de conceitos, é necessário interagir com a linguagem científica e, para tanto, compreender e desenvolver tal linguagem é tarefa da qual a escola nâo pode se furtar. A organizaçăo curricular para a formaçấo de cidadania deve privilegiar atividades de reflexăo sobre as ciências em diferentes campos do conhecimento e suas linguagens.

Apesar de considerarmos que o tema envolvendo a linguagem científica náo seja novo, no ensino de Língua Portuguesa, nas pesquisas e nas práticas, os textos da esfera científica têm ficado à margem, conferindo tal fato privilégio aos textos argumentativos, narrativos e de relato, conforme agrupamento ${ }^{8}$ de gêneros proposto para composiçấo de currículos de ensino básico, segundo Dolz e Abouzaid (2015). Rojo (2008) empreendeu pesquisa com a finalidade de analisar a apropriaçăo de gêneros de divulgaçăo científica na escola. Em tal empreendimento, verificou que apenas $18 \%$ dos textos de livros didáticos (LD) pertenciam à esfera da divulgaçăo científica. Os gráficos e infográficos, por exemplo, constituíam apenas 4\% dos textos de 144 manuais analisados. Com essa constataçăo de que "os gêneros de divulgaçâo científica nâo săo abordados no ensino" (ROJO, 2008, p. 581) embora estejam presentes nos LD, temos um tema de central relevância. Em recente levantamento feito em LD de Língua Portuguesa ${ }^{9}$, os resultados năo revelam equiparaçăo entre diferentes áreas do saber. Numa breve análise sobre as temáticas abordadas nos gêneros da esfera científica, as maiores porcentagens dizem respeito a meio ambiente, saúde e tecnologias digitais (em torno de $80 \%$ dos textos), enquanto as temáticas relativas às ciências humanas estăo sempre inferiores a 10\% dos conteúdos temáticos dos gêneros encontrados.

Pesquisadores vinculados ao campo do Ensino de Ciências e da Educaçăo Científica, que, de forma geral, envolvem professores das áreas das ciências "duras" têm abordado o discurso científico nas suas relaçôes com a escola, como um importante tema para a apreensăo de conhecimentos científicos. Santos e Mortmer (2001), por exemplo, defendem que a ciência năo é uma atividade neutra, ao contrário do que se concebia antes da década de 60; sendo assim, o movimento ciência, tecnologia e sociedade (CTS) surgiu como uma forma de se contrapor à visăo de "ciência por si mesma", que reivindicava da sociedade uma crença "cega" em seus resultados positivos, isolados de aspectos sociais, políticos, econômicos, culturais e ambientais.

As repercussōes desse movimento para a escola em geral sâo grandes. Considerar

80 agrupamento proposto (SCHNEUWLY; DOLZ, 2004) e retomado (DOLZ; ABOUZAID, 2015) prevê a organizaçâo curricular a partir de operaçōes de linguagem em gêneros textuais pertencentes a cinco domínios sociais da comunicaçâo e relativos à tipologias textuais, a saber: narrar, relatar, expor, argumentar e instruir. Os textos do expor sâo aqueles tipicamente de transmissăo de saberes e divulgaçáo científica.

9 Dados referentes à pesquisa em andamento "Letramento científico, gêneros textuais e educaçăo linguística" (UFJF - 2016 em diante). 
tal premissa na elaboraçăo de currículos para atingir uma educaçăo científica com vistas a tornar os alunos capazes de refletir sobre o conhecimento científico relacionado aos seus problemas do dia a dia e a tomarem decisōes com responsabilidade social é um aspecto que tem sido fortemente recomendado na área. Dessas, surgem novas discussōes, articuladas a letramento científico.

Santos (2007) utiliza o termo letramento científico com o intuito de dar destaque ao aspecto social do conhecimento científico aprendido na escola. Para o autor, letramento científico apresenta múltiplas dimensôes: um conjunto de práticas sociais que inserem o aluno em atividades de leitura e escrita das ciências; uma contextualizaçâo do conhecimento científico na vida cotidiana sem reduzi-lo a mero conhecimento prático acrítico; uma aprendizagem da ciência como fator cultural, uma aprendizagem da ciência atrelada a valores; uma defesa da aprendizagem da linguagem científica simultaneamente à apropriaçâo do conhecimento. Essa perspectiva dá grande relevância ao conhecimento científico numa perspectiva de contextualizaçăo social, sem reduzi-la, segundo o autor, a um aplicacionismo prático, mas enfatizando o valor cultural do conhecimento.

Suisso e Galieta (2015) defendem que as pesquisas que tematizam a leitura, a escrita e sua relaçáo com o ensino de ciências necessitam de maior rigor para relacioná-los, visto que tais relaçóes parecem estar superficiais. As autoras afirmam que pesquisas que têm como objeto AC/LC enfocam aspectos como "compreensáo da natureza da Ciência e a resoluçâo de problemas no dia a dia, e nâo com a discussáo das especificidades da leitura/escrita nas Ciências. A partir de análise de publicaçóes sobre a temática, os conceitos de AC/LC, segundo as autoras, "estabelecem vínculos superficiais considerando a associaçáo entre a aprendizagem de Ciências e de leitura/escrita na língua materna, e nâo a questăo da especificidade da aprendizagem da leitura/escrita nas Ciências" [grifos do original].

De fato, essas vertentes de pesquisas de letramento científico têm mostrado que o domínio da linguagem científica para o aprendizado das diferentes ciências na escola é fundamental. Ademais, os resultados de investigaçōes sobre LD de LP também revelam que a ausência de gêneros da esfera científica pode resultar em falta de domínio dessa linguagem; o acesso a práticas sociais com gêneros da esfera científica ${ }^{10}$, se presentes em materiais didáticos, currículos e salas de aula, propiciaria interaçăo entre estudantes e professores e outros sujeitos, pela oralidade e pela escrita, nessa esfera.

Suisso e Galieta (2015) são as que mais se aproximam daquilo que temos defendido como letramento científico no campo da Linguística Aplicada. Letramento científico năo envolve apenas leitura e escrita de textos científicos; tampouco se confunde letramento como capacidade leitora, como alguns autores sugerem. Letramento sâo as próprias práticas sociais que envolvem, para além da escrita, os comportamentos, as atitudes, os valores sociais e culturais, a ideologia, a conscientizaçăo sobre as

10 Vale destacar que tais aspectos também têm sido nosso foco, como o trabalho de pesquisa em currículos escolares (DALAMURA, MAGALHẢES, FONSECA, 2016) e materiais didáticos (MAGALHÁES, FONSECA, DALAMURA, no prelo; CORDEIRO, MAGALHÂES, 2017), pesquisas essas que têm contribuído com uma perspectiva restrita ao ensino de língua portuguesa na escola básica, na busca de propostas que substituam um ensino de gramática por uma reflexăo linguística, articulando os eixos da leitura, escrita e oralidade. 
estruturas de poder estruturante da esfera científica, bem como uma açâo investigativa, constitutiva da ciência e da aprendizagem na escola.

Nossas reflexôes sobre letramento científico advêm da complexidade do conceito de letramento, bem como da multiplicidade de práticas sociais que envolvem a escrita. Tais reflexóes estăo calcadas nos pressupostos de Street (2010, 2012, 2014), segundo o qual os conceitos de eventos e práticas de letramento săo problematizados; eventos podem ser definidos como as situaçóes concretas que envolvem a escrita. Segundo Heath (1982), sâo "qualquer ocasiâo em que um trecho de escrita é essencial à natureza das interaçóes dos participantes e a seus processos interpretativos (apud Street, 2010). Os eventos podem ser analisados sob diversos aspectos, o que permite ver certos "padrōes", que carregam significados, segundo Street (2010).

Práticas de letramento (STREET, 2003, 2014) săo os padrôes comportamentais, as conceitualizaçôes sociais e culturais da escrita, que incorporam os eventos e as ideologias que os sustentam. "Práticas de letramento sâo modos culturais gerais de utilizaçăo do letramento aos quais as pessoas recorrem num evento letrado" (BARTON, 1991, apud Street, 2014, p. 18). Autores como os mencionados, atrelados a uma perspectiva social de letramento, investigam práticas de escrita vinculadas a contextos específicos, e năo formas "universais" de escrita concebidas como habilidade técnica, que se "aplica" a qualquer contexto. Numa perspectiva social, letramento năo é habilidade mensurada em graus ou níveis, ou uma competência exclusivamente cognitiva; é, sim, uma prática, um processo.

Esses conceitos sâo potenciais para que as escolas desenvolvam eventos diversos que ultrapassem os padrôes escolares, o que produziria uma aprendizagem apenas de práticas de escrita "escolarizadas", concernentes ao letramento escolar. Assim, letramento científico deve envolver práticas investigativas que vâo sendo apropriadas à medida que eventos envolvendo pesquisar, questionar, analisar, relativizar săo realizados nas escolas, rompendo com os padrôes escolares de transmissâo do conhecimento e efetivando práticas de pesquisa na educaçáo básica e na formaçáo inicial de professores. Essas sâo as consequências de se sustentar a educaçâo no viés do letramento científico em diferente áreas, conforme atestam Silva, Tavares e Velez (2017) e Silva, Guimarâes e Medeiros (2018), que desenvolveram pesquisas em diferentes componentes curriculares na escola básica calcadas nos princípios do LC na vertente da LA.

Uma importante contribuiçâo para o campo do LC é a concepçăo proposta por Motta-Roth, que defende que ciência e tecnologia devem ser tomadas de forma ampla, envolvendo as diferentes áreas do conhecimento humano, "em todas as suas dimensôes (linguagem, música, matemática, artes visuais, biologia, literatura, etc.), para que possamos desenvolver um discurso inclusivo de todas as áreas do conhecimento como fundamentais para a qualidade de vida da sociedade (...)" (MOTTA-ROTH, 2011, p. 21). Essa concepçấo ampla de ciência evitaria que os livros didáticos, como os de LP mencionados acima, trouxessem subjacentes à concepçăo de ciência apenas pesquisas relacionadas às áreas como saúde, meio ambiente e tecnologias digitais, por exemplo. Para a autora, letramento científico năo envolve apenas de habilidades para ler e escrever nas ciências, mas envolve quatro dimensôes mais amplas: 
1) o conhecimento dos produtos da ciência e da tecnologia, dos sistemas simbólicos que as expressam e constroem, dos seus procedimentos, produtores e usuários (DURANT, 2005);

2) a atitude diante da experiência material ou mental, a abertura para mudança de opiniâo com base em novas evidências, a investigaçâo sem preconceito, a elaboraçáo de um conceito de relaçóes de causa e consequência, o costume de basear julgamentos em fatos e a habilidade de distinguir entre teoria e fato (MILLER, 1983, p. 31);

3) a compreensáo e a produçáo de textos e discursos que projetam opiniōes sobre ciência e tecnologia, pautadas pelo entendimento das relaçóes entre ciência e tecnologia e o mundo em que se vive (SANTOS, 2007);

4) a capacidade de fazer escolhas políticas que inevitavelmente advêm da consciência do impacto da ciência e da tecnologia na sociedade.

As dimensōes propostas por Motta-Roth (2011) nos ajudam a compreender que o letramento científico náo é a própria capacidade leitora, nem mesmo a linguagem científica, mas as "práticas investigativas informadas pela escrita em funçâo da produçâo de conhecimentos necessários ao desenvolvimento humano na complexidade que lhe é constitutiva em diferentes domínios sociais" (SILVA, 2016, p. 14). Pensando no ensino de LP, a escola, entâo, deve desenvolver práticas pedagógicas investigativas para apropriaçáo e desenvolvimento da linguagem recobrindo, para isso, conteúdos ou objetos do conhecimento relativos à língua enfocada, na interface com as outras disciplinas.

As repercussōes das discussōes sobre letramento científico nas práticas pedagógicas contemporâneas, relativas a qualquer componente curricular, avançam para superar a ideia de estudar a linguagem científica para aprender conceitos científicos, ou aprender conceitos para, entăo, apropriar-se de sua linguagem. Nessa concepçâo de letramento científico, conhecimento e linguagem estăo imbricados em processos escolares de investigaçâo, possibilitando desenvolvimento de pesquisas na educaçáo básica e na formaçăo de professores que superem a descriçâo ou identificaçăo de fenômenos. Permitem visualizar formas de se apropriar dos objetos do conhecimento de maneira problematizadora. Essa visăo engendra processos de aprendizagem menos dogmáticos, que se voltem nâo para transmissăo de conteúdos, mas para a compreensăo de fenômenos que compóem os diferentes componentes curriculares, articulando-os.

Nesse viés, há uma proposta de estudo das diferentes ciências numa perspectiva social, em que os objetos do conhecimento devem ser tratados partindo de uma concepçấo de ciência como uma das práticas sociais humanas. Tratando da aprendizagem escolar, os gêneros textuais e as capacidades de linguagem que os alunos devem desenvolver com base no estudo das operaçôes de linguagem envolvidas no fazer científico podem trazer importantes reflexôes para ampliar as práticas pedagógicas informadas por uma perspectiva investigativa de escolarizaçăo.

É nesse sentido que trazemos uma discussăo oriunda do Interacionismo Sociodiscursivo, que tem contribuído para inovaçôes no ensino de LP, deslocando os objetos de conhecimento escolares dos conteúdos linguísticos transmitidos assimetricamente aos alunos para uma apropriaçăo da linguagem por meio dos gêneros textuais em contextos de interaçăo diversos. 


\section{O INTERNACIONISMO SOCIODISCURSIVO E O DESENVOLVIMENTO HUMANO}

Uma contribuiçăo do ISD para a escola é propomos uma diferença entre "aprender linguagem" e "aprender as operaçōes que compôem as açōes de linguagem". Tal diferença é relevante e está no cerne das nossas discussóes: nossa concepçāo de língua vai muito além de um fato linguístico, mas envolve aspectos sociais, culturais, psicológicos, ideológicos, de forma que pontuamos o ISD como um campo transdisciplinar.

Assim, linguagem é concebida como atividade coletiva, como interaçăo humana entre sujeitos, que constrói identidades, carrega valores, veicula ideologias, bem como efetiva a interaçăo entre os seres humanos. Essa perspectiva na escola mostra que năo se trata de adquirir um conteúdo de linguagem, mas aprender a agir socialmente pela linguagem, deslocando o foco do conteúdo para as diferentes açóes humanas.

Na perspectiva do ISD, a problemática do agir é central, considerando que as atividades praxiológicas e de linguagem săo analisadas de forma conjugada. Os seres humanos agem em atividades coletivas, que săo as "estruturas de cooperaçâo/colaboraçâo que organizam as interaçōes dos indivíduos com o ambiente" (BRONCKART, 2006, p.138). Nessas estruturas, a linguagem também é concebida como um agir, que é ao mesmo tempo individual e coletivo, sendo tais atividades de linguagem diversificadas e dependentes das formaçôes sociais. As açóes de linguagem, efetivadas por uma pessoa, sâo apenas "uma parte da atividade de linguagem cuja responsabilidade é atribuída (por via externa ou interna) a um indivíduo singular, que, assim, se torna o agente ou o autor dessa açăo" (BRONCKART, 2006, p.139).

É nessa concepçâo que se coloca o desenvolvimento: tornar-se sujeito significa saber agir pela linguagem, visto que o desenvolvimento humano se dá pela apropriaçáo das açôes de linguagem e pela formaçăo do pensamento consciente.

Considerando, entâo, esse viés teórico que concebe as atividades praxiológicas e atividades de linguagem como imbricadas, os gêneros de texto sâo os modelos pré-construídos e legados pelas geraçōes anteriores (BRONCKART, 2010), espécies materializadas em textos que estáo cristalizados em determinados momentos, estabilizados pelo uso: "săo formaçōes sócio-linguageiras fechadas, organizadas segundo modalidades heterogêneas" (BRONCKART, 2003, p. 66). A apropriaçăo dos gêneros realizada pela mediaçâo pedagógica em "processos educativos explícitos" (BRONCKART, 2006, p. 129), confere a eles um status especial: os gêneros "respondem perfeitamente às exigências definidas por nossa concepçấo de desenvolvimento: sâo, a um só tempo, complexos e heterogêneos (...), produtos sócio-históricos, definíveis empiricamente, além de serem instrumentos semióticos para a açáo de linguagem" (SCHNEUWLY, 2004, p. 137).

Considerando que, na escola, um dos objetivos do ensino de línguas é o desenvolvimento de capacidades de linguagem dos alunos para agirem socialmente ${ }^{11}$, envolve-se nisso o aprendizado e o domínio das operaçôes de linguagem subjacentes aos gêneros. Com tal domínio, compreende-se que o sujeito está cada vez mais capaz de "operar", usar, manipular os gêneros textuais permitindo autonomia e (particip)açấo social. Para Bronckart (1999),

11 Consideramos aqui esses objetivos como orientaçôes oriundas de um conjunto de documento oficiais brasileiros, reflexóes de diversos autores do campo da LA e resultados de pesquisas e estudos desenvolvidos ao longo dos últimos 30 anos. 
(...) mostramos que aquilo que em uma língua "constitui sistema" (as categorias de unidades e as estruturas oracionais) năo pode ser considerado senăo como produto de um procedimento de abstraçăo operado sobre essas entidades funcionais e empiricamente observáveis que săo os textos: portanto, os textos săo primeiros e o sistema da língua năo é senâo um constructo secundário, a cuja elaboraçăo se consagraram geraçôes de gramáticos. Baseando-nos nessa modificaçăo radical de perspectiva teórica, poderíamos visualizar uma abordagem didática ideal, que consistiria em iniciar o ensino de língua pelas atividades de leitura e de produçáo de textos e que depois articularia, a esse procedimento inicial, atividades de inferência e codificaçăo das regularidades observáveis no corpus de textos mobilizado (BRONCKART, 1999, p. 86) [grifo nosso].

Nesse sentido, tanto na perspectiva do ISD quanto na do letramento científico, há propostas de inserçâo dos alunos em "práticas" de linguagem e de pesquisa, como fundamentais para a participaçăo social. Para tanto, é necessário que os discentes saibam lidar com as operaçóes de linguagem na leitura e na produçăo de textos para inserirem-se na esfera científica, a partir de situaçôes de mediaçăo de aprendizagem que partam da investigaçăo sobre os fenômenos linguísticos sugeridos nos LD, currículos orientadores ou projetos pedagógicos. A perspectiva de estudo das "regularidades observáveis no corpus de textos mobilizado" (BRONCKART, 1999) propóe abertura para uma prática reflexiva e investigativa no campo dos estudos de línguas na escola básica e na formaçăo de professores, o que já foi amplamente defendido por documentos oficiais e diferentes pesquisadores da LA.

A escola, nesse sentido, é central para mediar a aprendizagem dos gêneros e dos fenômenos linguísticos que os constituem, de forma reflexiva e năo descritiva ou transmissiva, visto ser a escola a instituiçáo por excelência veiculadora do conhecimento socialmente construído e valorizado, conduzindo o aluno a investigar, analisar, sistematizar, ou seja, a fazer pesquisa. Conforme afirmou Santos (2007), é preciso situar o conhecimento científico e dar sentido a ele. As duas perspectivas aqui conjugadas, letramento científico e ISD, podem sustentar uma pedagogia de línguas que rompa com a metalinguagem, tăo criticada desde a década de 80, mas que envolva proposiçôes de pesquisa e reflexăo sobre a língua, bem como divulgaçăo de seus resultados. A educaçâo científica está diretamente relacionada à educaçăo linguística (SANTOS, 2007; MOTTA-ROTH, 2011).

A revisăo de Suisso e Galieta (2015) parece lançar luz no que tange a "aprender a ler e escrever NAS ciências", no fazer científico, que pode ser cotidiano nas escolas, numa metodologia de ensino investigativa que proporcione expandir atitudes científicas, de descoberta, curiosidade e questionamento, no nosso caso relacionadas aos fatos linguísticos (em Língua Portuguesa e Inglesa).

Numa perspectiva de desenvolvimento que o ISD defende, năo basta conviver com os pré-contruídos; nas instituiçôes escolares, lidamos com um procedimento didático explícito de inserçăo dos novos membros nas atividades de linguagem. Assim, no letramento científico, em que a prática de pesquisa figura como central no processo de aprendizagem, trata-se de uma atividade, em constante construçâo, nova para os alunos, em que a inserçâo dos estudantes numa cultura de problematizaçâo, formulaçấo de questăo, implementaçăo de pesquisa em busca de resultados exige mediaçăo. Nesse caso, os membros de uma comunidade considerados mais "experientes" vấo inserindo 
os "novos membros" nesses pré-contruídos, que săo as açōes, os valores, as condutas verbais e năo verbais, conforme esclarece Bronckart. Essa inserçăo, na escola, refere-se aos

[...] processos deliberados por meio dos quais os adultos integram os "recémchegados" ao conjunto de pré-construídos disponíveis no ambiente sociocultural. Esse campo de análise diz respeito ao conjunto de processos de controle e avaliaçáo das condutas verbais e náo verbais que săo implementadas desde o nascimento (até o fim da vida), assim como os processos educativos explícitos que se realizam. principalmente, nas instituiçóes escolares (BRONCKART, 2006, p. 129). [grifo nosso]

Como resultado da relaçấo entre as duas perspectivas apesentadas acima, trazemos à tona algumas experiências que foram sustentadas pelos princípios teórico-conceituais que expusemos neste trabalho. Trata-se do desenvolvimento de projetos de letramento e sequências didáticas que propiciaram aos alunos desenvolver atividades de linguagem (folder, revistas, verbetes, livretos) cuja elaboraçâo abarcou uma atitude investigativa em relaçăo aos conteúdos/conhecimentos da língua, materna ou estrangeira, bem como envolveram diferentes temáticas sociais relevantes para a sociedade contemporânea (lixo, música, animais, bullying, meio ambiente), ou seja, no âmbito social, temas relevantes e pertinentes àquela comunidade onde se realizaram as propostas, evidenciando o engajamento social dos trabalhos; em relaçăo ao estudo da língua, os projetos e as sequências didáticas proporcionam uma "didática ideal", em que náo há um exercício metalinguístico e classificatório, com estudo da língua por si mesma, mas atrelado ao uso social que se faz dela. Assim, conforme Santos (2007) situamos o conhecimento, conferindo sentido para os sujeitos. Para além disso, proporcionamos a circulaçăo das produçóes dos alunos, que passamos a apresentar.

\section{PROPOSTAS DESENVOLVIDAS}

Durante os anos de desenvolvimento de pesquisas intervencionistas, realizadas no interior de nossos grupos de pesquisa, temos nos aproximado da escola para relativizar os conteúdos de ensino de língua materna e estrangeira, reduzir um estudo de língua "artificial" na escola, bem como realizar propostas em que há problematizaçâo e efetivaçấo de novas metodologias de ensino de línguas. Isso tem propiciado novas práticas pedagógicas escolares de reflexăo sobre a língua, tornando os estudantes e professores em sujeitos mais ativos, atrelando tal estudo à discussâo sobre temáticas socialmente relevantes para o mundo atual. Assim, pensamos em atividades que envolvessem reflexăo sobre a língua, seja na oralidade, seja na escrita, que apresentamos no quadro síntese a seguir.

Tais projetos foram orientados por nós contando com bolsistas de iniciaçâo científica (IC), bolsistas do Programa Institucional de Bolsa de Iniciaçăo à Docência (PIBID) ou extensâo e Treinamento Profissional ${ }^{12}$ juntamente a professores da escola básica, sendo esses docentes nossos supervisores do PIBID, mestrandos, doutorandos ou colaboradores de projetos institucionais. Ou seja, em todos os projetos, temos três partes/ agentes de um mesmo processo: orientadoras (professoras universitárias), professores

12 Modalidade de bolsa de Programa da Pró-Reitoria de Graduaçâao (PROGRAD) da UFJF. 
da escola básica (alunos de pós-graduaçăo, supervisores de PIBID ou projetos semelhantes ou colaboradores vinculados aos grupos de pesquisa) e bolsistas dos diferentes programas (de graduaçăo em licenciaturas em Letras - Português ou Inglês).

No Quadro 1, apresentamos apenas parte dos trabalhos desenvolvidos, uma vez que cada um deles aponta para uma complexidade tal que poderiam figurar como trabalhos independentes. De fato, vários já foram apresentados em outras publicaçôes, mas trazemos aqui essa junçăo de projetos no sentido de ilustrar as práticas investigativas e de reflexăo sobre conhecimentos e fenômenos linguísticos na educaçáo básica e na formaçăo de professores. 


\begin{tabular}{|c|c|c|c|}
\hline Ano & $\begin{array}{c}\text { Projeto/Sequência } \\
\text { didática }\end{array}$ & $\begin{array}{c}\text { Ano/ } \\
\text { componentes } \\
\text { curriculares }\end{array}$ & Síntese de etapas/atividades \\
\hline $2013 / 2016$ & $\begin{array}{l}\text { Revista “Na ponta } \\
\text { da Língua13 (temas: } \\
\text { música-2013; } \\
\text { ciência-2016; } \\
\text { cultura-2017) }\end{array}$ & $\begin{array}{c}6 \% / 7^{\circ} \text { do } \\
\text { EF Língua } \\
\text { Portuguesa, } \\
\text { História, Ciências }\end{array}$ & 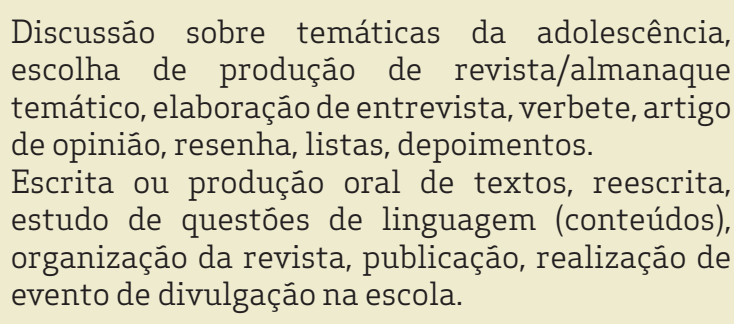 \\
\hline 2014 & $\begin{array}{l}\text { Ideias para salvar } \\
\text { o planeta - cartilha } \\
\text { sobre lixo14 }\end{array}$ & $\begin{array}{l}3^{\circ} \text { ano do } \\
\text { EF (Língua } \\
\text { Portuguesa, } \\
\text { Ciências) }\end{array}$ & $\begin{array}{l}\text { Pesquisa sobre rota do lixo em casa e na escola, } \\
\text { discussáo sobre meios para cuidar melhor do lixo, } \\
\text { entrevista, vídeo sobre } 3 \mathrm{R} \text { (reduzir, reutilizar } \\
\text { e reciclar), entrevista com vereador de Juiz de } \\
\text { Fora, produçấo oral e escrita de textos, reescrita, } \\
\text { estudo de conteúdos de LP, organizaçấ da } \\
\text { cartilha15, publicaçấo, distribuiçấo em campanha } \\
\text { de conscientizaçáo na escola. }\end{array}$ \\
\hline 2015 & Bichopédia16 & $\begin{array}{l}5^{\circ} \text { ano do } \\
\text { EF (Língua } \\
\text { Portuguesa, } \\
\text { Ciências) }\end{array}$ & $\begin{array}{l}\text { Estudo de animais na disciplina de Ciência; relaçáo } \\
\text { entre animais comuns e exóticos e os biomas } \\
\text { brasileiros; pesquisa em diversos meios e suportes } \\
\text { (sobre animais e biomas), escrita, reflexăo } \\
\text { sobre a língua e escrita, apresentaçăo oral, } \\
\text { organizaçáo dos textos, editoraçáo, publicaçấo da } \\
\text { "bichopedia17" (livro produzido pelos alunos). }\end{array}$ \\
\hline 2013 & $\begin{array}{c}\text { Verbete } \\
\text { enciclopédico }\end{array}$ & $\begin{array}{l}1^{\circ} . \text { ano Letras- } \\
\text { Inglês }\end{array}$ & 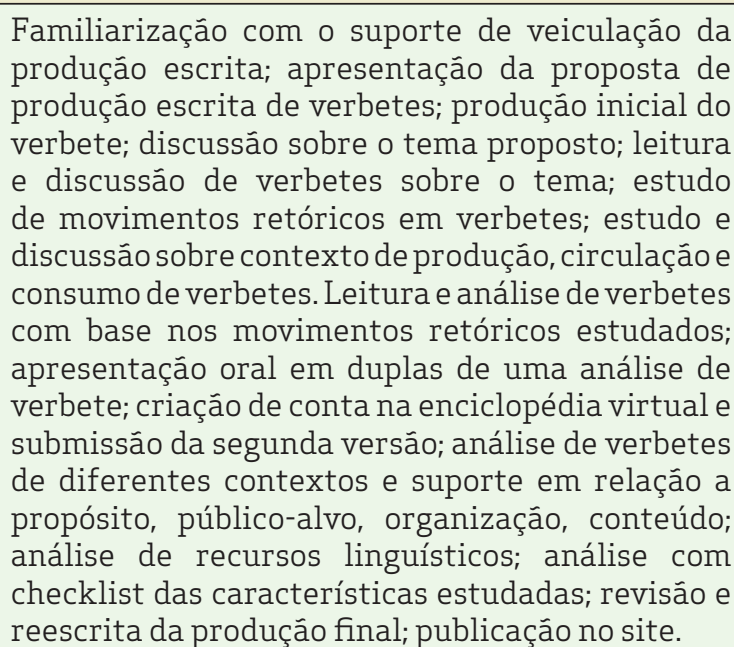 \\
\hline
\end{tabular}

Quadro 1 - sistematizaçâo dos projetos realizados

Fonte: elaborado pelas autoras

13 Projeto realizado no âmbito do PIBID, com 5 bolsistas de Letras, uma supervisora de uma escola estadual de Juiz de Fora (PIBID) e coordenado pela $1^{\mathrm{a}}$ autora do artigo (2013) e em atual projeto de Treinamento Profissional (UFJF) e extensăo (Letramento científico, gêneros textuais e educaçâo linguística).

14 Realizado por Ms. Vanessa Titonelli Alvim (com bolsa CAPES), orientado pela $1^{\text {a }}$ autora do artigo.

15 CARTILHA "IDEIAS PARA SALVAERMOS O PLANETA" http://www.youblisher.com/p/1074713-Ideiaspara-salvarmos-o-planeta/

16 Realizado por Ms. Anna Carolina Santos Reis Dalamura (com bolsa CAPES), orientada pela $1^{\mathrm{a}}$ autora do artigo.

17 BICHOPEDIA http://www.youblisher.com/p/1309127-Bichopedia/ 
Na escola básica, os trabalhos acima mostram que realizamos um percurso subjacente à concepçâo de língua e letramento que defendemos: partir das situaçôes/temáticas relevantes da comunidade, problematizar questôes instigantes para os alunos, propor questăo de estudo/investigaçăo, traçar caminho para buscar soluçóes/resultados, produzir dados (interagir pela língua - ler/falar, escrever/ouvir - e refletir sobre a língua), produzir textos/resultados, divulgar o produto/culminância do projeto. Nos projetos de elaboraçấo da cartilha educativa, em "Ideias para Salvar o Planeta" e na "Bichopédia" por exemplo, nâo apenas temáticas de relevância social foram abordados, como questóes sobre coleta de lixo, mas também no interior dos projetos práticas investigativas foram propostas. Houve ainda, uma prática reflexiva e questionadora dos objetos de aprendizagem relativos à língua: o questionamento diz respeito às motivaçóes para estudar língua (com conectores, pontuaçăo, gêneros textuais) e a melhor forma de fazê-lo, que, a nosso ver, é buscando evidências no uso cotidiano, que parta das próprias vivências dos alunos, no ensino de língua portuguesa na escola básica, para produzir conhecimento com circulaçấo social.

Na formaçăo inicial de professores voltada para língua estrangeira (nesse caso, Língua Inglesa), no ano de 2013, a disciplina de Produçấo Escrita do primeiro ano do curso da UEL propóe a leitura e produçăo de verbetes enciclopédicos como forma de promover letramentos e produçấo de conhecimento. As atividades desenvolvidas por meio de uma sequência didática que mediou o processo foram, a partir da prática social de produzir conhecimento sobre meio ambiente, e socializá-lo, os alunos produziram os verbetes e, para tanto, lançaram măo de reflexóes sobre grupos nominais, comparativos e superlativos, presente genérico e pretérito em língua inglesa, aspectos fundamentais para a construçâo e circulaçăo dos textos. A proposiçâo do tema "Meio ambiente e sociedade" foi parte do trabalho em prol da educaçăo ambiental com a qual também nós, profissionais da área de Linguagem, somos responsáveis. A relaçấo entre meio ambiente e sociedade em seus aspectos econômicos, ecológicos e de interferências antrópicas esteve subjacente à produçăo dos verbetes que, desde a proposta de sua produçấo, teve a enciclopédia virtual Everything $2^{18}$ como meio de circulaçấo. Ou seja, uma situaçâo de comunicaçăo foi apresentada; após a proposta de produçăo com meio de circulaçăo ser exposta, houve avaliaçâo diagnóstica, realizaçăo de sequência didática envolvendo leitura, produçăo, revisăo, reescrita, análise de movimentos retóricos em verbetes enciclopédicos, discussăo e pesquisa sobre conteúdos específicos e afins.

No Quadro 2, organizamos os objetos do conhecimento envolvido nos projetos, bem como as atitudes investigativas e a culminância de cada um dos projetos. 


\begin{tabular}{|c|c|c|}
\hline $\begin{array}{l}\text { Objetos do conhecimento } \\
\text { envolvidos (conteúdos de } \\
\text { línguas) }\end{array}$ & $\begin{array}{c}\text { Atitudes investigativas e científicas } \\
\text { envolvidas }\end{array}$ & $\begin{array}{l}\text { Produtos/culminância do } \\
\text { projeto }\end{array}$ \\
\hline $\begin{array}{l}\text { Gêneros - resenha, verbete, entre- } \\
\text { vista, artigos de opiniâo, reporta- } \\
\text { gem, panfleto; questóes lexicais, } \\
\text { sintáticas e semânticas (adjeti- } \\
\text { vaçăo, concordância verbal, tem- } \\
\text { pos verbais, etc); fatos históricos } \\
\text { relativos à ditadura; questôes de } \\
\text { Ciências sobre doenças mentais e } \\
\text { sua relaçăo com a musicoterapia; } \\
\text { questóes relativas a laticínios; } \\
\text { dentre outros }\end{array}$ & $\begin{array}{l}\text { Visitas guiadas (horto, feira científica, } \\
\text { universidade, teatro); discussão sobre } \\
\text { os impactos do(s) tema(s) na socieda- } \\
\text { de; levantamento de dados no bairro } \\
\text { e na escola por enquete; construçăo } \\
\text { de gráficos e tabelas para publicar o } \\
\text { levantamento; reflexão sobre a língua. }\end{array}$ & $\begin{array}{l}\text { Produçáo impressa e online } \\
\text { de duas versôes da Revista: } \\
\text { - "Música Na ponta da Lín- } \\
\text { gua"19" } \\
\text { - "Ciência na Ponta da Lín- } \\
\text { gua"0" } \\
\text { - "Cultura na Ponta da Lín- } \\
\text { gua"21 }\end{array}$ \\
\hline $\begin{array}{l}\text { Gêneros: exposiçâo oral, entre- } \\
\text { vista, HQ, propaganda, notícia, } \\
\text { cartilha, lei; questồes linguísticas: } \\
\text { relaçôes fala e escrita (exercícios } \\
\text { de retexutalizaçâo), variaçăo lin- } \\
\text { guística, pontuaçâo, títulos, bem } \\
\text { como questôes sobre apropriaçâo } \\
\text { do sistema de escrita alfabética) }\end{array}$ & $\begin{array}{l}\text { Entrevista com vereador da cidade, } \\
\text { pesquisa sobre formas de descarte de } \\
\text { lixo, discussáo sobre destino do lixo } \\
\text { produzido em casa e na escola, investi- } \\
\text { gaçáo sobre rota do lixo no bairro, pro- } \\
\text { blematizaçâo sobre o lixo nas grandes } \\
\text { cidades; reflexăo sobre a língua. }\end{array}$ & $\begin{array}{l}\text { Distribuiçăo, na comuni- } \\
\text { dade, de cartilha educativa } \\
\text { impressa sobre lixo elabo- } \\
\text { rada com textos e desenhos } \\
\text { dos alunos. }\end{array}$ \\
\hline $\begin{array}{l}\text { Gêneros: verbete; reflexăo sobre } \\
\text { formaçăo de palavras (bichonário } \\
\text { ou bichopedia); coesăo, conjun- } \\
\text { çôes, pronomes, pontuaçăo, } \\
\text { Ciências: biomas, tipos de animais, } \\
\text { nome científico. }\end{array}$ & $\begin{array}{l}\text { Discussăo sobre desmatamento e vida } \\
\text { dos animais domésticos ou silvestres; } \\
\text { investigaçăo sobre biomas brasileiros; } \\
\text { investigaçăo sobre tráfico de animais; } \\
\text { reflexâo sobre a língua. }\end{array}$ & $\begin{array}{l}\text { Divulgaçăo e doaçăo da bi- } \\
\text { chopedia para alunos de ou- } \\
\text { tras escolas do bairro. Rea- } \\
\text { lizaçâo do lançamento do } \\
\text { livro em evento na escola. }\end{array}$ \\
\hline $\begin{array}{l}\text { Conteúdos interdisciplinares; } \\
\text { movimentos retóricos do gênero; } \\
\text { conhecimento sobre o gênero re- } \\
\text { lacionado à dimensăo contextual } \\
\text { (tema [interdisciplinar], propósito } \\
\text { [projeto enunciativo], entre outras } \\
\text { características) e dimensáo tex- } \\
\text { tual [como organizaçâa textual, } \\
\text { recursos linguísticos]; abordagem } \\
\text { com base em gênero no ensino. }\end{array}$ & $\begin{array}{l}\text { Leituras e discussōes sobre diferen- } \\
\text { tes visóes compondo os conteúdos } \\
\text { interdisciplinares envolvendo o tema } \\
\text { proposto - meio ambiente e socieda- } \\
\text { de; escrita pública para circulação em } \\
\text { enciclopédia online; construção e dis- } \\
\text { seminação de conhecimento sobre um } \\
\text { tema; reflexăo sobre a língua. }\end{array}$ & $\begin{array}{l}\text { Publicaçáo de verbetes no } \\
\text { site https://everything } 2 . \\
\text { com }\end{array}$ \\
\hline
\end{tabular}

\section{Quadro 2 - Objetos, atitudes e produtos}

Fonte: elaborado pelas autoras

As produçôes acima possibilitam a vivência do que Motta-Roth (2011) defende como letramento científico: (produçăo de) conhecimento; atitude (investigativa e ética); compreensâo e produçấo de texto; e capacidade (humana e profissional) de contribuir

19 REVISTA MÚSICA NA PONTA DA LINGUA: http://www.youblisher.com/p/719903-Musica-na-ponta-da-lingua/

20 REVISTA CIÊNCIA NA PONTA DA LINGUA http://www.youblisher.com/p/1648202-Ciencia-na-Ponta-da-Lingua/

21 https://www.yumpu.com/pt/document/view/59717988/cultura-na-ponta-da-lingua ) 
para a sociedade. A produçấo de textos como processo permite "reformulaçăo, a necessidade de domínio de gêneros de texto que permitam ao sujeito agir socialmente, construir pensamento na escola" (PEREIRA; CARDOSO, 2013, p. 11).

Todavia, uma mudança de perspectiva no ensino de línguas, seja na escola básica, seja na formaçăo de professores, que "ressitue" os conteúdos de linguagem em práticas mais relevantes e participativas para os alunos, tem sido tarefa desafiadora para nós, formadores de professores, que, ao final deste texto, tomamos alguns aspectos, abaixo apresentados, como constataçôes para encaminhamentos de futuros projetos de pesquisa:

- a resistência, na cultura escolar e na universidade, em abandonar objetos de conhecimento tradicionais e cristalizados como essenciais para a aprendizagem: classificaçăo e memorizaçăo de conteúdos (relativos à morfologia e sintaxe por exemplo), como se fossem base para o desenvolvimento das capacidades de linguagem relativas à leitura, à escrita e à oralidade;

- a tensăo entre os projetos desenvolvidos por nós e a obrigatoriedade de se desenvolver outros em andamento nas escolas, relativos a temas mais abrangentes, presentes numa agenda escolar mais ampla (drogas, olimpíadas, copa do mundo, alimentaçấo etc);

- o estranhamento de alunos (da escola ou da universidade) e da comunidade (pais, por exemplo) no tocante à ausência de anotaçôes ou tarefas tradicionais (ausência de "matéria no caderno", na fala de alguns sujeitos), quando se prioriza uma atividade problematizadora, que parte de discussâo, questionamento, estudo teórico, caminho metodológico, montagem de corpus para análise, resultados, divulgaçăo/culminância dos projetos;

- o conflito entre atividades avaliativas, no interior das próprias propostas de SD e projetos pedagógicos (como por exemplo aquelas feitas no interior das reescritas de textos), e as tradicionais avaliaçôes bimestrais ou semestrais (em que, muitas vezes, o professor é obrigado a aplicar provas sobre os conteúdos estudados, sem autonomia para realizar avaliaçâo relativa às próprias produçôes dos alunos), o que nos revela a falta de discussăo sobre avaliaçấo nos cursos de licenciaturas, ou sua presença sem uma transposiçăo refletida;

- a estrutura escolar, muitas vezes precária, que năo oferece condiçōes para realizaçăo de eventos extra-classe, feiras científicas e culturais, havendo assim ausência de equipamentos básicos (como computadores, impressoras, datashow, televisăo e aparelho de DVD, filmadoras) bem como a falta de transporte de alunos para ambientes extra-escolares (museus, feiras, universidade, colégio técnico, horto, como foi feito nas nossas experiências da Revista "Na ponta da língua");

- a ausência de financiamento para divulgaçâo de materiais produzidos pelos alunos: folder impresso e colorido, em papel de qualidade; revista impressa (atualmente produzida somente online), cartilha, bichopédia etc; somente no 
caso do PIBID, que conta com financiamento da CAPES, houve possibilidade de impressâo do material que nâo fosse pago pelos próprios professores. Também nos projetos de pesquisa voltados à formaçăo de professores, aos quais temos acesso nas universidades e nas agências de fomento, conseguimos muitas vezes divulgar os materiais produzidos pelos alunos;

- uma constataçăo de que as propostas de projetos escolares e SD implementadas nas escolas alcançam a culminância com sucesso, tendo efetiva construçâo de conhecimento e circulaçăo social, quando fazem sentido e têm profunda relaçăo com as açóes cotidianas dos estudantes envolvidos. Assim, as práticas sociais nas quais os alunos se engajam é que vâo ser discutidas e problematizadas a partir da relevância do entorno escolar e/ou universitário, ganhando força para ir além do próprio meio onde os discentes já circulam. Isso permite uma aproximaçâo entre os sujeitos envolvidos nas pesquisas (como professores e alunos) e os sentidos produzidos por eles nas açōes empreendidas;

- uma descrença na capacidade do professor em realizar as atividades "sozinho", ou desdém pelo seu trabalho quando este tem ainda (felizmente) uma crença no poder transformador da educaçăo (descrença ou desdém por parte de outros professores ou coordenador pedagógico das escolas), uma vez que, nos trabalhos desenvolvidos, envolvemos professores pós-graduandos, ou vinculados a grupos de pesquisa universitários; nesse sentido, o discurso de oposiçăo ou resistência a bolsistas e pesquisadores nos espaços em que realizamos as atividades afeta o princípio de que a escola tem papel importante na sociedade atual, o que nos impulsiona para uma ampla discussáo sobre a identidade docente e suas condiçôes de trabalho.

Como ressaltamos, os princípios aqui apresentados têm também nos sustentado na formaçăo inicial e continuada de professores, instâncias nas quais temos apostado năo apenas na discussăo e implementaçăo de atividades de pesquisa na escola básica para a produçáo de conhecimento que parta do próprio contexto de atuaçăo profissional futura dos licenciandos, mas também na divulgaçăo desses trabalhos em revistas acadêmicas e eventos, como os exemplos de Garcia-Reis e Magalhăes (2016), cujos resultados pode ser vistos em Silva (2016). Nesse trabalho, os discentes desenvolveram um estudo de caso no interior de uma disciplina de graduaçăo em Letras - Português (Saberes Escolares de LP - UFJF), cujo princípio é articular horas de pesquisa em imersâo na escola básica (como atividade das Práticas Pedagógicas Curriculares) propondo investigar temas relativos à docência em língua materna. No ano de 2015, os graduandos de Letras produziram artigos, que foram publicados ao final da disciplina numa revista acadêmica. No ano de 2017, os alunos produziram banners, que foram apresentados em eventos acadêmicos na própria universidade.

Diante do que expusemos aqui, reforçamos nosso papel de pesquisadoras que devem investir no ensino de línguas vinculado a uma proposta investigativa, perpassando as práticas interdisciplinares que as concepçōes de letramento nos tem permitido realizar na educaçáo básica. 


\section{CONSIDERAÇÕES FINAIS}

Projetos como os aqui apresentados permitem-nos contribuir com uma transformaçáo de práticas educativas, rompendo com a proposiçăo de objetos de conhecimento aleatórios nas disciplinas de Língua Portuguesa e Inglesa na educaçăo básica e na formaçăo de professores. Rompe-se também com a ideia de que, se estăo citados em diretrizes ou livros didáticos, devem ser ensinados sem sequer propor uma problematizaçấo ou vinculaçăo à realidade escolar. Também permitem superar uma prática de ensino de linguagem baseada numa lógica transmissiva e cumulativa que, segundo Mendonça (2006), parte da descriçâo de unidades mínimas e nunca chega ao estudo do discurso, por exemplo.

A articulaçâo das vertentes teóricas aqui apresentadas, advindas de diferentes campos do conhecimento, possibilitou uma ressignificaçăo das práticas de linguagem na escola, articulando produçấo oral e escrita e pesquisa na educaçăo básica, o que resulta em apropriaçăo do conhecimento na escola via oralidade e escrita. A prática de ensino de línguas pelos gêneros confere ao processo de ensino maior autonomia na futura participaçăo social dos alunos que se dá pelo discurso.

Acreditamos no potencial que as concepçōes de letramento científico têm trazido para os estudos de linguagem, com repercussóes importantes para a relaçăo entre universidade e escola, principalmente no tocante à formaçấo de professores de línguas. A apropriaçăo de conhecimentos por alunos da escola básica ou pelos professores em formaçăo, a partir de diferentes teorias de linguagem e de aprendizagem, como as que foram citadas neste artigo, revelam que a participaçăo social dos sujeitos via linguagem é efetiva quando eles se apropriam dos gêneros.

Nesse sentido, esperamos que, com esta reflexăo, fruto de nossas pesquisas nos últimos anos, possamos contribuir para impulsionar novas práticas, envolvendo a relaçáo entre diferentes áreas de conhecimento e os diversos componentes curriculares da educaçăo básica, potencializando a formaçăo de professores, as práticas educativas no ensino de línguas no Ensino Fundamental e Médio, a elaboraçâo de materiais didáticos, a proposiçâo de currículos e avaliaçōes, de modo que tenhamos uma efetiva apropriaçấo de conhecimentos científicos de forma reflexiva e desafiadora. 


\section{REFERÊNCIAS}

BRONCKART, Jean Paul. Atividades de linguagem, textos e discursos: por um interacionismo sociodiscursivo. (trad. Anna Rachel Machado e Péricles Cunha). 2. ed. Sâo Paulo: EDUC, 1999.

BRONCKART, Jean Paul. Gêneros textuais, tipos de discurso e operaçóes psicolinguísticas. Revista de Estudos da Linguagem. Belo Horizonte, v. 11, n. 1, p. 49-69, jan-jun, 2003. Disponível em: http://www.periodicos.letras.ufmg.br/index.php/relin/article/ view/2344. Acesso em: mar. 2015.

BRONCKART, Jean Paul. Atividades de linguagem, discurso e desenvolvimento humano. (org. Anna Rachel Machado; Maria de Lourdes Meirelles Matencio; trad. Anna Rachel Machado; Maria de Lourdes Meirelles Matencio (et al). Campinas-SP: Mercado de Letras, 2006.

BRONCKART, Jean Paul. Gêneros de textos, tipos de discurso e sequências. Por uma renovaçăo no ensino da produçăo escrita. Revista Letras. Santa Maria, v. 20, n. 40, p. 163-176, 2010. Disponível em https://periodicos.ufsm.br/letras/article/view/12150. Acesso em março de 2015

CHASSOT, Ático. Educaçâo conSciência. Santa Cruz do Sul. EDUNISC, 2003.

CORDEIRO, Ariane Alhadas. Gêneros textuais na escola: um estudo do gênero relatório científico. Dissertaçăo. Mestrado em Educaçăo. Programa de Pós-Graduaçâo em Educaçấo. Universidade Federal de Juiz de Fora, 2017.

CORDEIRO, Ariane Alhadas; MAGALHÂES, Tânia Guedes. A escrita do relatório científico na escola básica: o que dizem os professores. Revista Veredas. v. 21, especial, p. 359-398, 2017. Disponível em www.uff.br/revistaveredas. Acesso em: dez. 2017.

CUNHA, Rodrigo Bastos. Scientific literacy: alfabetizaçăo ou letramento? Implicaçōes políticas da traduçâo de um conceito. ComCiência, n.140. Campinas, jul. 2012. Disponívelem http://www.scielo.br/scielo.php?script=sci arttext\&pid=S1413-24782017000100169. Acesso em: maio 2016.

DALAMURA, Anna Carolina Santos Reis; MAGALHĂES, Tânia Guedes; FONSECA, Thayane Viana Gêneros textuais e ensino de Ciências: uma análise da Proposta Curricular de Ciências da Prefeitura de Juiz de Fora (MG). Revista Instrumento. Juiz de Fora, vol. 18, n. 1, 2016. Disponível em: https://instrumento.uff.emnuvens.com.br/revistainstrumento/ article/view/2890/1990. Acesso em: novembro de 2017.

DEBOER, George. Scientific Literacy: another look at its historical and contemporary meanings and its relationship to Science Education Reform. Journal of research in Science Teaching. v. 37, n. 6, p. 582- 601, 2000. Disponível em: http://onlinelibrary.wiley.com/doi/10.1002/1098-2736(200008)37:6\%3C582::AID-TEA5\%3E3.0.CO;2-L/epdf Acesso em: jun. 2016. 
DOLZ, Joaquim, ABOUZAID, Myriam. Pluralidade dos gêneros e singularidade do texto: tensôes constitutivas da didática das línguas. Revista Linha D'Água (Online), Sâo Paulo, v. 28, n. 2, p. 5-25, dez 2015. Acesso em agosto de 2016. Disponível em: http://www.revistas.usp.br/linhadagua/article/view/105440. Acesso em: jun. 2016

PAULA, Helder de Figueiredo e; LIMA, Maria Emília Caixeta Castro. Educaçăo em ciências, letramento e cidadania. Química nova na escola. Sáo Paulo, n²6, 2007. Disponível em http://qnesc.sbq.org.br/online/qnesc26/v26a02.pdf. Acesso em: 07 nov. 2013.

GARCIA-REIS, Andreia Rezende; MAGALHĂES. Tânia Guedes. As experiências de escrita na formaçăo de professores de Língua Portuguesa: uma prática no curso de Letras da UFJF. In: Letramentos e práticas de ensino. Campinas, SP: Editora Pontes, 2016. p. 35-52.

GOMES, Anderson Stevens Leônidas. (org.) Letramento Científico: um indicador para o Brasil. Săo Paulo: Instituto Abramundo. 2015. Acesso em agosto de 2015. Disponível em http://acaoeducativa.org.br/wp-content/uploads/2014/10/ILC_Letramento-cientifico um-indicador-para-o-Brasil.pdf. Acesso em: maio 2016.

HEATH, Shirley Brice. Ways with words: Language, life, and work in communities and classrooms. Cambridge: Cambridge University Press, 1983.

HURD, Paul DeHart. Scientific literacy: new minds for a changing world. Science Education. vol. 82, 408-416. 1997. Disponível em http://onlinelibrary.wiley.com/ doi/10.1002/(SICI)1098-237X(199806)82:3\%3C407::AID-SCE6\%3E3.0.CO:2-G/pdf

Acesso em: maio 2016.

LAUGKSCH, Rüdiger. Scientific Literacy: a conceptual overview, Science Education, vol. 84, Issue 1, pp.71-94, 2000. Disponível em http://onlinelibrary.wiley.com/ doi/10.1002/(SICI)1098-237X(200001)84:1\%3C71::AID-SCE6\%3E3.0.CO:2-C/epdf Acesso em: maio 2016.

KRASILCHIK, Myriam; MARANDINO, Martha Ensino de ciência e cidadania. 2. ed. Sâo Paulo. Moderna, 2007.

MARTINS, Isabel. Letramento científico: um diálogo entre Educaçâo em Ciências e estudos de discurso. In: MARINHO, M. CARVALHO, G. T. (orgs) Cultura escrita e letramento. Belo Horizonte: Editora da UFMG, 2010.

MENDONÇA, Márcia Rodrigues de Souza. Análise linguística no ensino médio: um novo olhar, um outro objeto. In: BUNZEN, C.; MENDONÇA, M. (org) et al. Português no ensino médio e formaçâo do professor. Sáo Paulo: Parábola Editorial, 2006.

MILLER, Jon D. Scientific literacy: a conceptual and empirical review. Daedalus, v. 2, n. 112, p. 29-48, 1983. Disponível em https://edisciplinas.usp.br/pluginfile.php/844760/mod resource/content/1/MILLER_A_conceptual overview_review.pdf Acesso em: maio 2016.

MORTIMER, Eduardo Fleury; VIEIRA, Ana Clara Figueiredo Rodrigues; ARAÚJO, Angélica Oliveira de. O. Letramento científico em aulas de química. In: Cultura escrita e letramento. MARINHO, M.; CARVALHO, G. T. (orgs). Belo Horizonte: Editora da UFMG, 2010. 
MOTTA-ROTH, Désirée. Letramento científico: sentidos e valores. Notas de Pesquisa, Santa Maria, RS, v.1, p.12-25, 2011. Disponível em: https://periodicos.ufsm.br/nope/ article/view/3983/2352. Acesso em: julho 2016.

PEREIRA, Luísa Álvares; CARDOSO, Inês. (ORG.) Reflexâo sobre a escrita: o ensino de diferentes gêneros de textos. Aveiro: Universidade de Aveiro Editora, 2013.

ROJO, Roxane. O letramento escolar e os textos da divulgaçâo científica: a apropriaçăo dos gêneros de discursos na escola. Linguagem em (Dis)curso. v. 8, n 3, p.581-612, set/ dez.2008. Disponível em: http://www.scielo.br/pdf/ld/v8n3/09.pdf Acesso em: jun. 2013.

SANTOS, Wildson Luiz Pereira. Educaçâo científica na perspectiva de letramento como prática social: funçōes, princípios e desafios. Revista Brasileira de Educaçáo, Rio de Janeiro, v. 12, n. 36 set./dez. 2007. Disponível em http://www.scielo.br/pdf/rbedu/ v12n36/a07v1236.pdf Acesso em junho de 2014.

SANTOS, Wildson Luiz Pereira; MORTIMER, Eduardo Fleury. Tomada de decisăo para açăo social responsável no ensino de ciências. Ciência e Educaçāo (UNESP), v. 7, n.1, p. 95-111, 2001. Disponível em http://www.scielo.br/scielo.php?script=sci_arttext\&pi$\mathrm{d}=$ S1516-73132001000100007 Acesso em março de 2013.

SCHNEUWLY, Bernard; DOLZ, Joaquim (e colaboradores) (trad. Roxane Rojo e Glaís Sales Cordeiro). Gêneros orais e escritos na escola. Campinas: Mercado de Letras, 2004.

SILVA, Wagner Rodrigues. Letramento científico na formaçāo inicial do professor. Revista Práticas de Linguagem. v. 6, especial, 2016. Disponível em: http://www.uff.br/ praticasdelinguagem/files/2017/01/2-Artigo-Wagner.pdf. Acesso em: jan. 2017.

SILVA, Wagner Rodrigues. Formaçăo sustentável do professor no mestrado profissional. Revista Brasileira de educaçâo. [online]. 2017, vol.22, n.70, p.708-731. Disponível em: http://www.scielo.br/pdf/rbedu/v22n70/1809-449X-rbedu-22-70-00708.pdf. Acesso em: dez. 2017.

SILVA, Wagner Rodrigues; GUIMARĂES, Elton Vieira; MEDEIROS, Ivanildo Alves. Construçăo de objetos de conhecimento para aulas de língua portuguesa na abordagem do letramento científico. Revista Brasileira de Linguística Aplicada. Belo Horizonte: UFMG. (no prelo)

SILVA, Wagner Rodrigues; SOUSA, Waldeny Berson de; ARAÚJO, Solange Freire Castro. Construçăo de saberes no mestrado profissional em Letras: uma experiência compartilhada. Leia escola, Campina Grande, v. 17, n. 1, p. 32-44, 2017. http://revistas.ufcg.edu. br/ch/index.php/Leia/article/view/848/497. Acesso em: dez. 2017.

SILVA, Wagner Rodrigues; TAVARES, Elcia; VELEZ, Luciana de Carvalho Barbalho. Trabalho pedagógico com escrita em aula de história: o que dizem as diretrizes oficiais? Trabalhos em Linguística Aplicada. Campinas: Unicamp, v. 56, n.3, p. 885-911, 2017. Disponível em: https://periodicos.sbu.unicamp.br/ojs/index.php/tla/article/ view/8649155/17469. Acesso em: dez. 2017

STREET, Brian. What's 'new' in New Literacy Studies? Critical approaches to literacy in theory and practice. Current Issues in Comparative Education. 5(2) May 12. Pp. 77-91, 2003. Disponível em: http://devweb.tc.columbia.edu/i/a/document/25734_5_2_Street. pdf.Acesso em: jan. 2015. 
STREET, Brian. Os novos estudos sobre letramento: histórico e perspectivas. In: MARILDES, M.; CARVALHO, G. T. Cultura escrita e letramento. Belo Horizonte: Editora da UFMG, 2010.

STREET, Brian. Eventos de letramento e práticas de letramento: teoria e prática nos novos estudos de letramento. In: MAGALHĂES, Isabel. (org). Discursos e práticas de letramento: pesquisa etnográfica e formaçăo de professores. Campinas, SP: Mercado de Letras, 2012.

STREET, Brian. Letramentos sociais: abordagens críticas do letramento no desenvolvimento, na etnografia e na educaçāo. (Trad. Marcos Bagno). Sáo Paulo: Parábola, 2014.

SUISSO, Carolina; GALIETA, Tatiana. Relaçōes entre leitura, escrita e alfabetizaçăo/letramento científico: um levantamento bibliográfico em periódicos nacionais da área de ensino de ciências. Ciência e Educaçâo, Bauru, v. 21, n. 4, p. 991-1009, 2015. Disponível em: http://www.scielo.br/scielo.php?pid=S1516-73132015000400013\&script=sci_abstract\&tlng=pt Acesso em: dez. 2016.

TEIXEIRA, Francimar Martins. Reflexōes sobre o que é alfabetizaçāo científica. Ciência e Educaçâo, Bauru, v. 19, n. 4, p. 795-809, 2013. Disponível em: http://www.nutes.ufrj.br/ abrapec/viiienpec/resumos/R1059-1.pdf Acesso em: ago. 2015.

Recebido em dezembro de 2017.

Aceite em fevereiro de 2018. 